\title{
Heat Use Efficiency of Indian mustard (Brassica juncea) at Different Phenophases in Western Haryana, India
}

\author{
Mohammad Ahatsham*, Surender Singh and Chandra Sekhar Dagar \\ Department of Agricultural Meteorology CCSHAU, Hisar-125004, Haryana, India \\ *Corresponding author
}

\section{A B S T R A C T}

\begin{tabular}{|l|}
\hline Ke y w or d s \\
$\begin{array}{l}\text { Indian mustard (Brassica } \\
\text { juncea), Phenophases, } \\
\text { Western Haryana }\end{array}$ \\
\hline Article Info \\
\hline $\begin{array}{l}\text { Accepted: } \\
\text { 19 May } 2018 \\
\text { Available Online: } \\
\text { 10 June } 2018\end{array}$ \\
\hline
\end{tabular}

\section{Introduction}

Mustard is grown in tropical and temperate climate and is grown in winter season. Among all the weather parameters, temperature plays a significant role in better establishment, growth, development and finally the yield of crop. It requires about $18-25^{\circ} \mathrm{C}$ temperature and low humidity for better crop growth. During seed germination and maturity stage slightly high temperature is required. Optimum temperature is $25{ }^{\circ} \mathrm{C}$. Rainfall, cloudiness and extreme cold and frost are harmful for the crop (Mukherjee et al., 2014). Rabi crops are very sensitive to high temperature especially during reproductive stage. Each phenophase of a particular crop has an optimum temperature for its initiation and development and changes in this optimum temperature affects the yield of a crop mainly through changes duration of phonological stages because of influence on plant physiological processes including photosynthesis. Fluctuation in daily temperature during growing season of crop has significant impact on increase and decrease in production and productivity. Temperature is the major factor governing the success and timing of agricultural crop production. Germination, average growth rate, growth duration and biomass production are controlled by temperature. Under late sown condition, productivity declines primarily due to the shortening of vegetative and reproductive phase. Processes of seed formation are highly variable and depend on 
genetic, environmental and agronomic factors as well as interactions between them (Sidlauskas and Bernotas, 2003).

\section{Materials and Methods}

Experiments were conducted during rabi seasons of 2014-15 and 2015-16 at research farm of Agricultural Meteorological farm of Chaudhary Charan Singh Haryana Agricultural University, Hisar $\left(29^{0} 10^{\prime} \mathrm{N}, 75^{0}\right.$ 46' E and 215.2m a.m.s.l.). The experiment was laid out in split plot design with four replications. Treatment combination comprised of three dates of sowing viz., $\mathrm{D}_{1}\left(1^{\text {st }}\right.$ fortnight of Oct.), $\mathrm{D}_{2}$ ( $2^{\text {nd }}$ fortnight of Oct.) and $\mathrm{D}_{3} \quad\left(1^{\text {st }}\right.$ fortnight of Nov.) with five varieties Laxmi $\left(\mathrm{V}_{1}\right)$, RH0749 $\left(\mathrm{V}_{2}\right)$, Kranti $\left(\mathrm{V}_{3}\right)$, RH $406\left(\mathrm{~V}_{4}\right)$ and $\mathrm{RH} 30\left(\mathrm{~V}_{5}\right)$. The variation in sowing dates was kept to create different crop growing environments.

The crop was closely observed at an interval of 2-3 days for the commencement of different phenological stages viz., $\quad \mathrm{P}_{1}$-Seedling emergence, $\mathrm{P}_{2}$-Early vegetative phase (four leaf stage), $\mathrm{P}_{3}$-Flowering initiation (when 50 $\%$ of plants in plot have at least one open flower), $\mathrm{P}_{4}$-Pod initiation (when $50 \%$ of plants in plot have at least one pod $2.0 \mathrm{~cm}$ long), $\mathrm{P}_{5^{-}}$Seed development (when $50 \%$ of plants in plot have at least one pod with fully developed seeds) and $\mathrm{P}_{6}$-Physiological maturity. The total dry matter accumulation was taken at each above mention phenophases. Air temperature data used in this study were recorded at Agromet Observatory which situated within $10 \mathrm{~m}$ of the experimental site. Growing degree days (GDD) were calculated by simple arithmetic accumulation of daily mean temperatures above a base temperature value of $5{ }^{0} \mathrm{C}$ considered for winter crops (Nuttonson, 1955). Thereby, Growing degree days (GDD) is represented as

$$
\Sigma\left[\mathrm{T}_{\max }+\mathrm{T}_{\min }\right]
$$

Growing Degree Days $(G D D)=\frac{}{2}-T_{\text {base }}$

Where,

$\mathrm{T}_{\max }=$ Maximum Temperature $\left({ }^{0} \mathrm{C}\right)$

$\mathrm{T}_{\text {min }}=$ Minimum Temperature $\left({ }^{0} \mathrm{C}\right)$

$\mathrm{T}_{\text {base }}=$ Base Temperature $\left(5^{0} \mathrm{C}\right.$ for mustard $)$

Heat use efficiency (HUE) has been defined in terms of dry matter production as ratio of amount of above ground biomass produced per plant at maturity and accumulated heat units during crop season (Rao et al., 1999). It was calculated as follows:

Dry matter accumulation g, plant ${ }^{-1}$ Heat Use Efficiency (HUE) = Accumulated GDD $\left({ }^{0} \mathrm{C}\right.$ days $)$

\section{Results and Discussion}

\section{Growing Degree Days}

Accumulated growing degree days were significantly different at emergence in different sowing dates during both the crop seasons because number of days taken to emergence was lower in $\mathrm{D}_{1}$ ( $1^{\text {st }}$ fortnight of Oct.) sowing followed by $\mathrm{D}_{2}\left(2^{\text {nd }}\right.$ fortnight of Oct.) and $\mathrm{D}_{3}$ ( $1^{\text {st }}$ fortnight of Nov.) (Table 1 and 2). Accumulated GDD was higher under early sown crop at all growth stage and phenophases till maturity. This can be due to more growing period available to early sown mustard. The accumulated GDD at maturity was recorded higher during 2015-16 probably due to increased maturity period because of supra-optimal thermal stress as compare to 2014-15. In case of varieties, maximum GDD consumed were by RH 0749 under both the crop seasons followed by Laxmi, RH 406, RH 30 and Kranti, this may be due to their genetic characters. Similar findings have also been reported by Singh et al., (2014). 
Table.1 Heat use efficiency (g plant ${ }^{-1}{ }^{0} \mathrm{C}$ day, $10^{3}$ ) of mustard varieties at different phenological stages under various growing environments during 2014-15

\begin{tabular}{|c|c|c|c|c|c|c|c|c|c|c|c|c|c|c|c|}
\hline \multirow[t]{2}{*}{ Treatments } & \multicolumn{3}{|c|}{ Early vegetative phase } & \multicolumn{3}{|c|}{$50 \%$ Flowering } & \multicolumn{3}{|c|}{ Pod initiation } & \multicolumn{3}{|c|}{ Seed development } & \multicolumn{3}{|c|}{ Physiological maturity } \\
\hline & GDD & DM & HUE & GDD & DM & HUE & GDD & DM & HUE & GDD & DM & HUE & GDD & DM & HUE \\
\hline \multicolumn{16}{|c|}{ Dates of sowing } \\
\hline $\mathbf{D}_{1}$ & 261 & 1.4 & 5.5 & 762 & 15.2 & 20.0 & 890 & 22.8 & 25.6 & 1015 & 44.8 & 44.1 & 1470 & 50.7 & 34.5 \\
\hline $\mathbf{D}_{2}$ & 227 & 1.0 & 4.4 & 686 & 12.1 & 17.6 & 841 & 17.5 & 20.8 & 967 & 37.7 & 39.0 & 1343 & 45.7 & 34.0 \\
\hline $\mathbf{D}_{3}$ & 205 & 0.7 & 3.6 & 642 & 7.3 & 11.3 & 819 & 12.7 & 15.5 & 1001 & 31.9 & 31.9 & 1283 & 35.3 & 27.5 \\
\hline \multicolumn{16}{|c|}{ Varieties } \\
\hline $\mathbf{V}_{1}$ & 238 & 1.1 & 16.8 & 718 & 12.0 & 16.8 & 860 & 18.1 & 21.0 & 984 & 41.0 & 41.7 & 1395 & 48.6 & 34.8 \\
\hline$V_{2}$ & 251 & 1.2 & 18.0 & 716 & 12.9 & 18.0 & 884 & 19.7 & 22.3 & 1027 & 45.0 & 43.8 & 1414 & 52.9 & 37.4 \\
\hline$V_{3}$ & 215 & 0.9 & 15.1 & 670 & 10.1 & 15.1 & 820 & 16.0 & 19.5 & 968 & 31.6 & 32.7 & 1327 & 36.0 & 27.1 \\
\hline$V_{4}$ & 231 & 1.1 & 16.8 & 697 & 11.7 & 16.8 & 848 & 17.7 & 20.9 & 993 & 38.2 & 38.5 & 1356 & 43.0 & 31.7 \\
\hline$V_{5}$ & 222 & 1.0 & 15.7 & 693 & 10.9 & 15.7 & 836 & 16.8 & 20.1 & 980 & 34.9 & 35.6 & 1345 & 39.1 & 29.1 \\
\hline
\end{tabular}

Table.2 Heat use efficiency (g plant ${ }^{-1}{ }^{0} \mathrm{C}$ day, $10^{3}$ ) of mustard varieties at different phenological stages under various growing environments during 2015-16

\begin{tabular}{|c|c|c|c|c|c|c|c|c|c|c|c|c|c|c|c|}
\hline \multirow[t]{2}{*}{ Treatments } & \multicolumn{3}{|c|}{ Early vegetative phase } & \multicolumn{3}{|c|}{ 50\% Flowering } & \multicolumn{3}{|c|}{ Pod initiation } & \multicolumn{3}{|c|}{ Seed development } & \multicolumn{3}{|c|}{ Physiological maturity } \\
\hline & GDD & DM & HUE & GDD & DM & HUE & GDD & DM & HUE & GDD & DM & HUE & GDD & DM & HUE \\
\hline \multicolumn{16}{|c|}{ Dates of sowing } \\
\hline $\mathbf{D}_{1}$ & 379 & 1.7 & 4.5 & 785 & 17.4 & 22.2 & 934 & 26.0 & 27.8 & 1231 & 53.1 & 43.1 & 1969 & 64.1 & 32.6 \\
\hline $\mathbf{D}_{2}$ & 339 & 1.4 & 4.0 & 704 & 12.7 & 18.1 & 852 & 20.3 & 23.8 & 1074 & 44.6 & 41.5 & 1755 & 53.7 & 30.6 \\
\hline $\mathbf{D}_{3}$ & 324 & 0.9 & 2.8 & 627 & 8.6 & 13.7 & 736 & 14.2 & 19.3 & 929 & 33.4 & 36.0 & 1619 & 40.4 & 25.0 \\
\hline \multicolumn{16}{|c|}{ Varieties } \\
\hline $\mathbf{V}_{1}$ & 347 & 0.6 & 1.6 & 714 & 13.9 & 19.5 & 853 & 21.4 & 25.1 & 1089 & 49.4 & 45.3 & 1802 & 56.1 & 31.1 \\
\hline$V_{2}$ & 369 & 0.6 & 1.7 & 734 & 15.5 & 21.1 & 877 & 23.5 & 26.8 & 1105 & 55.7 & 50.4 & 1832 & 63.2 & 34.5 \\
\hline$V_{3}$ & 329 & 0.4 & 1.3 & 674 & 10.9 & 16.1 & 811 & 16.8 & 20.7 & 1055 & 33.2 & 31.5 & 1735 & 44.7 & 25.7 \\
\hline$V_{4}$ & 353 & 0.5 & 1.5 & 710 & 12.7 & 17.9 & 837 & 20.2 & 24.1 & 1079 & 42.6 & 39.5 & 1777 & 52.1 & 29.3 \\
\hline$V_{5}$ & 339 & 0.5 & 1.4 & 694 & 11.6 & 16.7 & 826 & 19.0 & 23.0 & 1062 & 37.7 & 35.5 & 1759 & 47.8 & 27.2 \\
\hline
\end{tabular}




\section{Dry Matter Accumulation}

The dry matter accumulation increased till physiological maturity among all the treatments during both crop seasons. The increase in dry matter of plants was due to increase in plant height, growth and development of plant organs. The highest dry matter was accumulated in $\mathrm{D}_{1}\left(1^{\text {st }}\right.$ fortnight of Oct.) at all the growth intervals till physiological maturity, whereas the minimum dry matter accumulation was recorded $\mathrm{D}_{3}\left(1^{\mathrm{st}}\right.$ fortnight of Nov.) during both the crop seasons.

The crop of $\mathrm{D}_{1}$ date of sowing has utilized more solar radiation at early vegetative phase as well as more favourable climate at reproductive phase and grand growth phase which resulted in higher biomass, LAI and better partitioning. These similar finding supported by Gill and Bains (2008). However, $\mathrm{D}_{3}$ late sown crop during vegetative phase suffered low temperature and utilized less radiation, whereas, at grand growth phase and reproductive phase due to higher temperature and terminal heat stress resulted into reduced reproductive phase and forced to early maturity.

The findings of Kar and Chakravarty (2000), Singh and Singh (2005), Kalra et al., (2008) and Tripathi et al., (2005) are also supported these results. Neog et al., (2013) also confirmed that delayed planting decreases the dry matter production. In 2014-15, the accumulation of dry matter and its allocation to different plant parts was drastically reduced due to delayed sowing $\left(\mathrm{D}_{3}\right)$ because of abnormal weather conditions. The highest biomass in earlier sown crop and variety $\mathrm{RH}$ 0749 might be due to maximum LAI and more PAR absorption by this variety. Among the varieties, the biomass accumulation in different plant parts of RH 0749 was significantly higher followed by Laxmi, RH
406, RH 30 and Kranti in irrespective of the growth intervals during both the years. The highest dry matter in earlier sown crop and variety RH 0749 might be due to maximum LAI and more PAR absorption by this variety. The varieties performed same trend of dry matter allocation as the sowing dates for the different growth intervals. In all plant parts, dry matter accumulation was higher by $\mathrm{RH}$ 0749 as compared to other four varieties during year 2014-15 and 2015-16. Similar finding supported by Srivastava et al., (2000).

\section{Heat Use Efficiency}

The highest heat use efficiency was recorded in $\mathrm{D}_{1}$ sown crop and lowest were in $\mathrm{D}_{3}$ sowing date in both the crop seasons. Heat use efficiency with delay in sowing found decreased in $\mathrm{D}_{3}$ and significantly reduction in yield as compare to $\mathrm{D}_{1}$ sown crop. Similar report finding by Gupta et al., (2017). Among the varieties, RH 0749 recorded highest HUE values followed by Laxmi, RH 406, RH 30 and lowest in Kranti during both the crop seasons. This was due to reason that Kranti had produced lowest biomass as compared to other cultivars under the same environment.

The delayed in sowing reduced the HUE significantly. The accumulation of HUE was higher at all the phenophases during the 201516 as compared to 2014-16. This was due to less dry matter production and less number of accumulated thermal times was consumed in delayed sown crops. Similar results were reported by Sengupta et al., (2003).

In conclusion, delayed in sowing reduced the heat use efficiency, less dry matter production and less number of accumulated thermal times was consumed in delayed sown crops. Early sown crop (October) accumulated highest GDD, Dry matter and HUE in $\mathrm{D}_{1}\left(1^{\text {st }}\right.$ fortnight of Oct.) and RH 0749 varieties. 


\section{References}

Ahmadi, B., Hosein, A., Rad, S. and Delkhosh, B. (2014). Evaluation of plant densities on analysis of growth indices in two canola forage (Brassica napus L.). European journal Experimental Biology, 4 (2): 286-294.

Akhter, S., Singh, L., Saxena, A., Rasool, R., Jan, R., and Showqi, I. (2016). Agrometeorological indices for brown sarson (Brassica rapa L.) sown under different dates of sowing in temperate region of Kashmir. The bioscan, 11 (1): 279-283.

Gupta, M., Sharma, C., Sharma, R., Gupta, V. and Khushu, M.K. (2017). Effect of sowing time on productivity and thermal utilization of mustard (Brassica juncea L.) under sub-tropical irrigated conditions of Jammu. Journal of Agrometeorology, 19 (2): 137-141.

Kar, G. and Chakravarty, N.V.K. (2000). Phenological stages and growth dynamics of Brassica as influenced by weather. Journal of Agrometeorology., 2 (1): 39-46.

Mukherjee, A., Banerjee, S., Mukherjee, S., Samanta, S. and Chakraborty, A.J. (2014). Agrometeorological requirements and management practices of rapeseed mustard in Gangatic West Bengol, AICRP on Agrometeorology (Mohanpur Centre), Directorate of
Research, BCKV, West Bengal, India. pp 32.

Neog, P., Sarmah, K, and Rajbongshi, R. (2013). Thermal indices in rapeseed grown in the North Bank Plain Zone of Assam. Journal of Agrometeorology., 15 (2): 174-177.

Nuttonson, M. Y. (1955). Wheat -climate relationships and use of phenology in ascertaining the thermal and photothermal requirements of wheat. American Institute of Crop Ecology, Washington D.C. pp 388.

Rao, V.U.M., Diwan, Singh and Singh, Raj, (1999). Heat use efficiency of winter crop in Haryana. "Journal of Agrometeorology, 1 (2): 143-148.

Sengupta, S., Kale, A.A. and Das, H.P. (2003). Assessment of phenology, heat and radiation use efficiency, thermal growth rate and phenophasic development model of chickpea at peninsular India. Mausam, 54 (3): 711716.

Sidlauskas, G. and Bernotas, S. (2003). Some factor affecting seed yield of spring oilseed rape (Brassica napus L.). Agronomical Research., 1 (2): 229-243.

Tripathi, M.K., Singh, D., Rao, V.U.M. and Singh, Raj. (2005). Biomass partitioning in Indian mustard (Brassica juncea L.) under different growing environments. Haryana Journal Agronomy., 21 (2): 179-182.

\section{How to cite this article:}

Mohammad Ahatsham, Surender Singh and Chandra Sekhar Dagar. 2018. Heat Use Efficiency of Indian mustard (Brassica juncea) at Different Phenophases in Western Haryana, India. Int.J.Curr.Microbiol.App.Sci. 7(06): 1977-1981. doi: https://doi.org/10.20546/ijcmas.2018.706.234 